\title{
STRESS AMONG LADY HEALTH WORKERS: A SPECIAL REVIEW OF PAKISTAN
}

\author{
Muhammad Hashim \\ PhD. Scholar, Department of Sociology, University of Sargodha \\ hashimsocial@yahoo.com \\ Yasir Nawaz Manj \\ Associate Professor, University of Sargodha \\ yasir.manj@gmail.com \\ Muqaddas Tanvir Cheema \\ $\mathrm{PhD}$ scholar, Department of Sociology and Criminology, \\ University of Sargodha
}

\begin{abstract}
Lady health workers are playing a central role for community health, upgrading of nations, all over Pakistan, particularly their role for polio eradication. Lady health workers faced whole set of troubles, in equally in their family as well as in their professional lives. They take part in their duty as a companion, mothers as well as an earner. Objectives of research are to explain in what ways lady health works feel stress. To unpack the causes of stress: among lady health workers. There is review of 22 research papers related to lady health workers 'fields activities and stress felt during job while maintaining their customary role that overlap responsibilities. Hence, customary laws are one of them means of stress. To working lady health workers, encompass through. The current review article focuses on working lady health workers stress, several aspects in their work setting, which is grounded in their nature of work, whereas during hard-to-reach pockets during community engagement activities face issues related to negative attitude that also increase the stress. After reading the maximum research papers it is concluded that there is lack of research on issues faced by LHV's. Policy makers and research organization are not taking actual information on the base of subjectivity that may be differ at al level, so the papers explained regards the managerial issue's, low educated LHV's. Government new policies and less educated LHV's that facing issue regarding data sharing and field work.
\end{abstract}

Keywords: Stress, Lady health workers, Community development, Rural areas, Campaign

\section{INTRODUCTION}

Lady Health workers (LHWs) are the (FLW's) who are skilled to aid basic healthcare services, health educations to their concern cover areas, that is mostly near to their house or she is living at that village, with in UC of that community. The total number of (LHWs) is more than forty-eight thousand approximately in Punjab. Every LHW provide health education and community meetings to 1000 families in to her assigned areas. For this she needs to ensure 10-15 household's visits every working day as per government calendar. They are responsible as per Job descriptions for maintaining complete records of family eligible marriage couples, under 15-year girls and boys, the (PW) Pregnant women record along with polio campaign data and fields work activities during, SIA's, further more daily dairy record, like register, Routine Immunization, as well as family planning (FP) related record. LHWs act as vital health education promoter for the successful rescue and explanation of national intervention such as (PEI)Polio Eradication Initiative (Zaidi et al., 2020)

There is communicational gap among the community health need and health system. Moreover, in spite of low income a key portion was being used upon tertiary care (level) consequently neglect (Bhu's ) primary health care to the (RHC) rural health center's inhabitants (Anwar, 2006).

The Government of Pak through the hold up of WHO, show its obligation by beginning a community health workers programme recognized as the "National Programme for Family Planning and Primary Health Care (FP\&PHC)" in 1994. The Programme widely recognized as "Ladies Health 
Workers Programme" (LHWP), has be able to collect community contribution during society need creation through mobilization, awareness as well as carry about change in position about essential issue of health plus family development/planning by establish an inclusive grass roots stage flourishing system for state of primary health care(PHC)(Ronis et al., 2007).

This analysis furthermore work-related to field stress faced by (LHV's) lady health workers good thing its connection, all the way through self-perceived comfort in addition sick leave and operational work of CHW's. The results convey it to light that the main factor cause stress and bounded by them is 'stress allocated; unfavorable circumstances follow by 'augmented workload. Women allied with 'high perceived stress continuing to inferior like salary linked by means of conflicts' are daily monthly report taking along with additional sick leaves (Gyllensten\& Palmer, 2005).Anxiety at learning is growing difficulty for all employees, as well as women. Furthermore, in FLW's levels of strain: associated poor health is virtually elevating the stress to manifold (Abdullah et al., 2008).

Stephen Palmer and Kristina Gyllensten (2005) explain numerous aspects like lack of occupational development, favoritism, discrimination along with stereotype are main reason that constructs stress connecting the women. They argue that women report privileged, high level of stress seeker; compare with male (Gyllensten \& Palmer, 2005; Lottrup et al., 2013).

The (LHW) of the Pakistan they are part of National Programme designed for Family Planning furthermore (PHC) Primary Health Care generally fits into the significance of (CHW) community health worker along with thesis a vital aspect of health care, make public understanding of the nation healthcare system. This is federally finance; advance programme and implemented at the grass root phase since 1994, relating to 96,000 workers along with their supervisor have been taught in addition to arrange in all the 135 districts of Pakistan. They are 65\% from target population of rural along with urban slums (Bhuvaneshwari \& Management, 2013).

There is no usually recognized standard designed for stress assessment. A number of examine studies by means of (obtainable stress, dimension and process) like psychological measures of stress measurements as well as biological indicator: have been performed, furthermore, learning on HRV and stress are mounting in frequency. HRV is the rise and fall of the length of heartbeat interval Heart rate variability increase at some stage in relaxing and recovering activities along with decreases during stress time this change occur from day to day on the base of activity level and workrelated stress. Also it's up to external and internal stress factors (Omer et al., 2008).

\section{Objectives}

- To explain in what ways lady health works, feel stress.

- To unfold the cause of stress situations among LHV's.

The Review of papers, (Lehmann et al., 2007)explain that ladies health worker (LHW'S) generally troubled at once in numerous tasks, that cause stress among family as well as work every day jobs that leads towards stress among them (Haq et al., 2008)explore, various roles, require of career development, inequity in addition to stereotype is the factor that creates stress for women. They deeprooted that women privileged as a high level of stress if compared to male

Bhuvaneshwari, (2013) exposed that stress is committed operational women was reason owing to a diversity of family and official commitment, harassment at field, extensive hours work and inappropriate workload. Such factors lead to stress in during fields activities like expanded headaches, high blood pressure and heaviness. She also accomplished that pressure can be minimized with matching work as well as family, with institutional hold, to spend some moments of their leisure time by doing some physical exercise. Douthwaite et al., (2005) stated thatthe Lady Health Worker's unrestricted entree to households, complimentary communication through confined women furthermore established high point suitability have render them suitable in addition to reliable programme for Mother Neonatal Child Health $(\mathrm{MNCH})$ examine source at the community stage, LHW's are deploy within communities to suggest essential health care encompass a variety of title but CHW word frequently used to portray this cadre. According to WHO:" CHW must be members of the society anywhere they employed, must be preferred by the community, must be accountable to community intended for their behavior, be supposed to by the health structure but not basically a component of its society, and comprise less trained in respect of professional workers. So LHW's play a vital role in civilizing, augmentation plus exposure of health provision, services condition which is hard-to-reach to their, own pockets. Mumtaz et al., (2003) reported offensive administration 
configuration, disrespect commencing male colleagues as well as perceptive to gender-based cultural constriction, conflict to effort; responsibility and disadvantaged infrastructural support, along with significant harms face by feminine PHC. The study conducted in 1998.The study suggests that women's face disregard from male while work related responsibilities was improved. The success is raising the implementation of contraceptives by means of rural women. Serve by Ladies Health Workers was notably more possible to apply up to date contraceptive method than women in community does not provide by LHW at the back calculating for different human being as well as family unit. They advocate for continuation of given that approach all the way through communitybased human resources to accomplish general right to use to safe family planning method. Study guided that communication on kin planning is immobile alleged as a composite area by these staff while the planned be theoretical to be sustained, a quantity of(IPC) interpersonal communication, ability, construction procedures to additional improve performance along with output. Douthwaite et al., (2005) argued that it is now documented that stress in the on the economic increase countries are a serious community health wellbeing issue, predict to be converted into the most frequent cause of disability from 2020.

Murray et al., (1996) explain the reason for this increased frequency is not clear in addition to a better understanding of etiology is essential if intervention is to be successful. promising explanation comprise social adversity, particularly poverty, poor schooling and deprived access to health treatment, complex, perhaps by cultural beliefs regarding depressive. Closser, (2011) reported that the UNICEF research department conducted interview, the enormous mass of LHWs with other (FLW's)frontline polio staff said their income is not enough for basic needs of life: food, transport, along with housing. Family income approximately, lower -US2 $\$$ a day per individual other hand other staff also. Female polio staffs said with the intention of small pay; de-motivate their encouragement.

Figure 1, the selection of relevant research papers/articles process is given below.

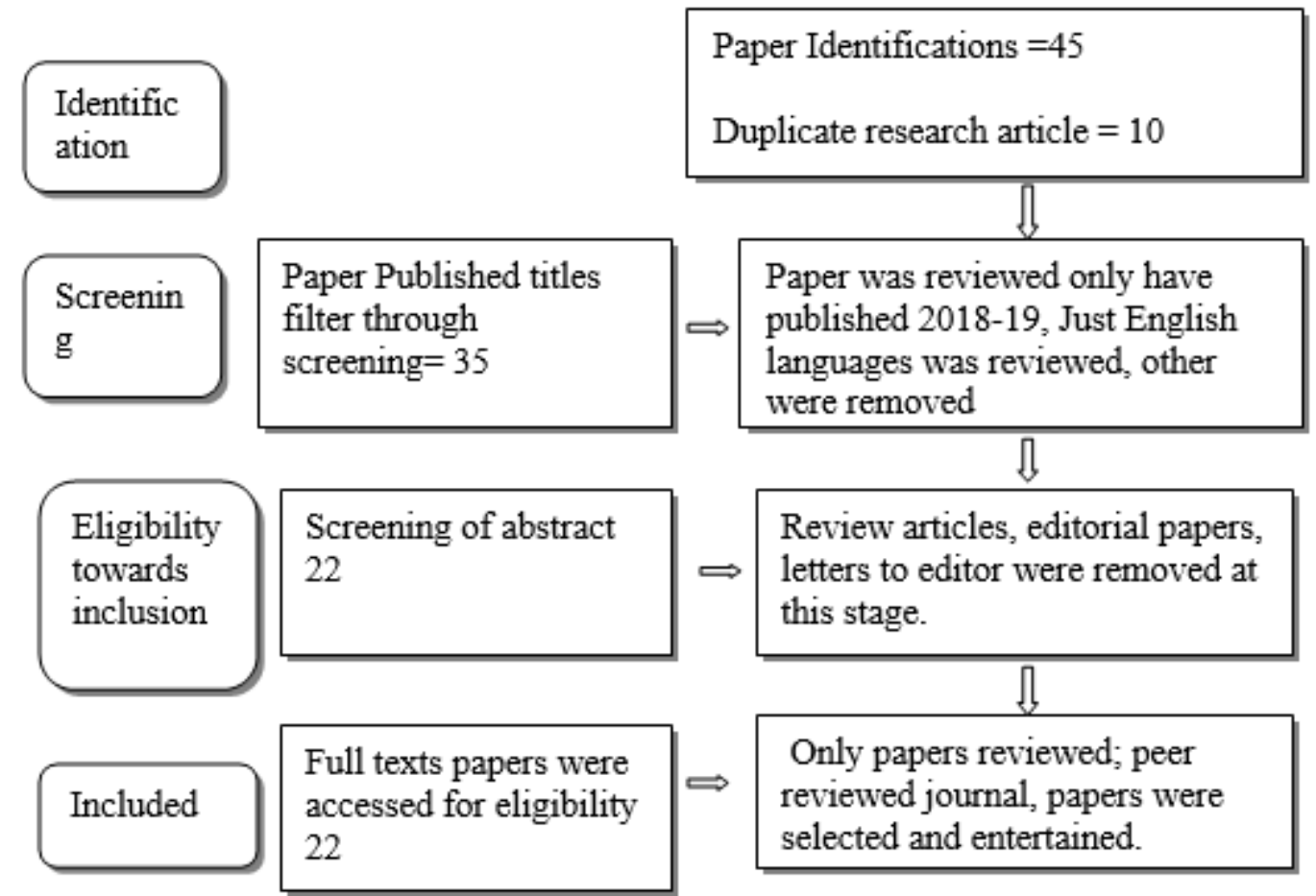

Below table will unveil the basic screening data of reviewed article, here in will shared the used methodology, sample size, timeline, expected population and remarkable outcome of reviewed.

\section{METHODOLOGY}

The reviewer has identified 45 relevant papers whereas 10 were duplicate and searched, Paper Published titles filter through screening were 35, and Paper were reviewed only have published 201819, Just English languages were reviewed, other were removed Full texts papers were accessed for eligibility. Only papers reviewed; peer reviewed journal, papers were selected and entertained finally were 22.if unpack the research methodology, over all paper were have abstract and all were scanned 
and fully red twice a time of all 45 paper and 22 papers, abstract along with research methodology, target population, research design, total and target population, sampling technique, data collection tool, case studies, FGD'S were mostly red. Maximum were used interviews, survey, case-study, FGD'S were used as data collection tools also Synthesis of papers and systematic review were used. Desk review, reports documents review, field validation, Thematic analysis, Qualitative methodology were used; mostly design was descriptive used.

\begin{tabular}{|c|c|c|c|c|c|c|}
\hline $\begin{array}{l}\text { Abstrac } \\
\text { t } \\
\text { scanned } \\
\text { \& Red } \\
\text { twice / } \\
\text { elected } \\
\text { Populat } \\
\text { ion }\end{array}$ & Methods & $\begin{array}{l}\text { Reviewed/f } \\
\text { inal } \\
\text { selection }\end{array}$ & \multicolumn{2}{|c|}{ Results/ findings } & $\begin{array}{l}\text { Conclusio } \\
\text { n }\end{array}$ & Recommendations \\
\hline $\begin{array}{l}\text { Yes/341 } \\
0(36)\end{array}$ & $\begin{array}{l}\text { Thematic } \\
\text { analysis } \\
\text { of } \\
\text { 4countrie } \\
\text { s data, } \\
\text { Qualitati } \\
\text { ve. }\end{array}$ & $\begin{array}{l}\text { Yes, } \\
\text { incorporati } \\
\text { on of } \\
\text { health } \\
\text { innovation } \\
\text { keen on } \\
\text { health } \\
\text { system, } \\
\text { guide for } \\
\text { major } \\
\text { review. }\end{array}$ & $\begin{array}{l}\text { Ethiopia, } \\
\text { India, } \\
\text { Brazil, } \\
\text { Pakistan / } \\
\text { CBHW }\end{array}$ & $\begin{array}{l}\text { Training } \\
\text { and } \\
\text { retraining } \\
\text { discrimin } \\
\text { ation }\end{array}$ & $\begin{array}{l}\text { Include } \\
\text { the } \\
\text { political } \\
\text { and } \\
\text { communit } \\
\text { y elders }\end{array}$ & $\begin{array}{l}\text { Highly skilled trainers, } \\
\text { scale up, gradation and } \\
\text { ensure compatibility to } \\
\text { health system, } \\
\text { inadequate. } \\
\text { Infrastructure and } \\
\text { vaccine supply govt } \\
\text { adopt step wise } \\
\text { approach, government } \\
\text { financing training [16] }\end{array}$ \\
\hline $\begin{array}{l}\text { Yes/313 } \\
200\end{array}$ & $\begin{array}{l}\text { Multimet } \\
\text { hod study } \\
\text {,6,FGD, } \\
\text { survey, } \\
\text { stratified } \\
\text { random } \\
\text { sampling }\end{array}$ & $\begin{array}{l}\text { LHVs, Dr., } \\
\text { midwifes. }\end{array}$ & $\begin{array}{l}\text { Rural } \\
\text { /200 } \\
\text { LHWs, } \\
20 \text { Bhu,2 } \\
\text { RHC, 28 } \\
\text { Dr,12mid } \\
\text { wives, 15 } \\
\text { vaccinato } \\
\text { rs (150, } \\
\text { LHWs) }\end{array}$ & $\begin{array}{l}\text { Mental } \\
\text { stress. } \\
\text { Distance } \\
\text { from bhu } \\
\text { is very } \\
\text { long }\end{array}$ & $\begin{array}{l}26 \% \\
\text { LHW's of } \\
\text { national } \\
\text { programm } \\
\text { e are } \\
\text { mentally } \\
\text { feel } \\
\text { distressed, } \\
\text { lack of } \\
\text { career } \\
\text { path }\end{array}$ & $\begin{array}{l}\text { IPC skill are not being } \\
\text { Enhanced third party } \\
\text { evaluations, LHW's own } \\
\text { opinions, scaling } \\
\text { up-task force, optional } \\
\text { carrier's advancement } \\
\text { for future (Haq et al., } \\
\text { 2008) }\end{array}$ \\
\hline Yes/NA & $\begin{array}{l}\text { period of } \\
1 \mathrm{y} \\
(2007- \\
08) \\
\text { descripti } \\
\text { ve study }\end{array}$ & $\begin{array}{l}\text { Desk } \\
\text { review of } \\
\text { project } \\
\text { papers, } \\
\text { MIS } \\
\text { manageme } \\
\text { nt } \\
\text { information } \\
\text { system, } \\
\text { reports, } \\
\text { Interviews, } \\
\text { discussions } \\
\text {, formal } \\
\text { and } \\
\text { informal, } \\
\text { stakeholder } \\
\text { s, NGO's, }\end{array}$ & Pakistan & $\begin{array}{l}\text { Not } \\
\text { mention }\end{array}$ & $\begin{array}{l}97 \% \\
\text { LHV's } \\
\text { qualificati } \\
\text { on is } 8^{\text {th }} \\
\text { class } \\
\text { schooling } \\
\text { or more. }\end{array}$ & $\begin{array}{l}\text { There are } 90,000 \text { LHWs } \\
\text { All over the Pak, } 44000 \text {, } \\
\text { per annum expenses } \\
\text { by the government, } \\
\text { economic constraint\& } \\
\text { political interfere } \\
\text { leading to administration } \\
\text { issues.[(Hafeez et al., } \\
\text { 2011) }\end{array}$ \\
\hline
\end{tabular}




\begin{tabular}{|c|c|c|c|c|c|c|}
\hline & & $\begin{array}{l}\text { governmen } \\
\text { t ministries, } \\
\text { all } \\
\text { department } \\
\text { s included } \\
\text { line }\end{array}$ & & & & \\
\hline $\begin{array}{l}\text { Yes/4 } \\
\text { UC'S. }\end{array}$ & $\begin{array}{l}1990 \\
\text { joining } \\
\text { LHV's } \\
\text { was } \\
\text { interview } \\
\text { ed }\end{array}$ & $\begin{array}{l}\text { interviews } \\
\& \text { FGDs }\end{array}$ & $\begin{array}{l}\text { Rural /4 } \\
\text { UC's } \\
\text { were } \\
\text { selected }\end{array}$ & $\begin{array}{l}\text { Not } \\
\text { mention }\end{array}$ & $\begin{array}{l}\text { Resistance } \\
\text { in the } \\
\text { LHV's as } \\
\text { regards } \\
\text { women's } \\
\text { decision } \\
\text { to tieas } \\
\text { (HW). } \\
\text { Women's } \\
\text { feel stress } \\
\text { especially } \\
\text { during } \\
\text { work }\end{array}$ & $\begin{array}{l}\text { The patriarchal context } \\
\text { and a strict set of gender } \\
\text { norms, values, } \\
\text { household based, } \\
\text { mobility } \\
\text { Overcoming these } \\
\text { possible barriers as well } \\
\text { as } \\
\text { creating a slot } \\
\text { "Qatron Wali Baji } \\
\text { a polio } \\
\text { health workers. } \\
\text { (Chaudhry, 2019) }\end{array}$ \\
\hline Yes/NA & $\begin{array}{l}\text { Not } \\
\text { mention }\end{array}$ & $\begin{array}{l}\text { Interview } \\
\text { and desk } \\
\text { analysis, } \\
\text { review of } \\
\text { literature }\end{array}$ & $\begin{array}{l}\text { Not } \\
\text { mention }\end{array}$ & $\begin{array}{l}\text { Not } \\
\text { mention }\end{array}$ & $\begin{array}{l}\text { Over work } \\
\text { load and } \\
\text { traditional } \\
\text { ways to } \\
\text { deal with } \\
\text { LHV's, } \\
\text { multiple } \\
\text { responsibi } \\
\text { lities of } \\
\text { job and } \\
\text { family } \\
\text { create } \\
\text { issues. }\end{array}$ & $\begin{array}{l}\text { Traditional roles are } \\
\text { the key source of } \\
\text { stress that operational } \\
\text { Female encompass to } \\
\text { face. } \\
\text { (Swathi et al., 2016) }\end{array}$ \\
\hline $\begin{array}{l}\text { Yes/ } \\
3001 \\
\text { articles, } \\
\text { then } 153 \\
\text { finally } \\
\text { selected } \\
111\end{array}$ & $\begin{array}{l}\text { Synthesis } \\
\text { of papers } \\
\text { and } \\
\text { systemati } \\
\text { c review. }\end{array}$ & $\begin{array}{l}\text { Systematic } \\
\text { review \& } \\
\text { conceptual } \\
\text { framework; } \\
\text { Jan } 2008 \text { to } \\
\text { April } 2018 .\end{array}$ & $\begin{array}{l}\text { Asia- } \\
\text { Pacific }\end{array}$ & $\begin{array}{l}\text { Cost- } \\
\text { effective } \\
\text { and } \\
\text { feasible } \\
\text { approach } \\
\text { to } \\
\text { deliverin } \\
\text { g critical, } \\
\text { life- } \\
\text { saving } \\
\text { services } \\
\text { to the } \\
\text { whole } \\
\text { populatio } \\
\text { n. } \\
\text { Generate } \\
\text { s trust }\end{array}$ & $\begin{array}{l}\text { building } \\
\text { manageria } \\
1 \text { ability; } \\
\text { institution } \\
\text { alizing } \\
\text { communit } \\
\text { y meeting; } \\
\text { 'moderniz } \\
\text { ing PHC } \\
\text { informatio } \\
n \text { systems. }\end{array}$ & $\begin{array}{l}\text { Society engagement } \\
\text { range from 'light touch' } \\
\text { session } \\
\text { through to extra } \\
\text { substantive } \\
\text { effort as component of } \\
\text { a co-design } \\
\text { approach. Such } \\
\text { approaches augment } \\
\text { suitability for } \\
\text { services, and promote } \\
\text { community } \\
\text { admiration trust (Dodd } \\
\text { et al., 2019) }\end{array}$ \\
\hline Yes/250 & $\begin{array}{l}\text { cross- } \\
\text { sectional } \\
\text { survey } \\
\text { design }\end{array}$ & $\begin{array}{l}\text { non- } \\
\text { experiment } \\
\text { al, } \\
\text { correlation } \\
\text { and }\end{array}$ & $\begin{array}{l}\text { Iran } \\
\text { (Ahvaz)/ } \\
\text { study } \\
\text { during } \\
2010\end{array}$ & $\begin{array}{l}\text { occupatio } \\
\text { nal } \\
\text { stress' }\end{array}$ & $\begin{array}{l}\text { Working } \\
\text { women } \\
\text { plus their } \\
\text { family. } \\
\text { There is a }\end{array}$ & $\begin{array}{l}\text { important positive } \\
\text { relationship among } \\
\text { levels of } \\
\text { occupational pressure, } \\
\text { stress (Zarra-Nezhad et }\end{array}$ \\
\hline
\end{tabular}




\begin{tabular}{|c|c|c|c|c|c|c|}
\hline & & $\begin{array}{l}\text { regression } \\
\text { analysis. } \\
\text { Random } \\
\text { sampling }\end{array}$ & & & $\begin{array}{l}\text { huge } \\
\text { require for } \\
\text { study on } \\
\text { effective } \\
\text { women. }\end{array}$ & al., 2010) \\
\hline $\begin{array}{l}\text { Yes/193 } \\
\text { 9/ 2,59 } \\
\text { Final. }\end{array}$ & $\begin{array}{l}\text { two- } \\
\text { phase } \\
\text { survey, } \\
\text { house-to- } \\
\text { house } \\
\text { survey }\end{array}$ & $\begin{array}{l}\text { Psychiatric } \\
\text { Assessment } \\
\text { Schedule } \\
\text { (PAS, } \\
\text { Multivariat } \\
\text { e analysis }\end{array}$ & $\begin{array}{l}\text { Pakistan } \\
\text { (Mundra, } \\
\text { Islamaba } \\
\text { d, Grand } \\
\text { Trunk } \\
\text { road }\end{array}$ & $\begin{array}{l}\text { high } \\
\text { frequenc } \\
\text { y of } \\
\text { depressiv } \\
\text { e } \\
\text { disorder } \\
\text { in } \\
\text { Pakistan, }\end{array}$ & $\begin{array}{l}\text { A total of } \\
259 \\
\text { people } \\
\text { were } \\
\text { screen, } \\
145,56 \\
\text { percent be } \\
\text { feminine, } \\
\text { there be } \\
\text { eight } \\
\text { refusals } \\
\text { (98\% } \\
\text { reply rate) }\end{array}$ & $\begin{array}{l}\text { judgment of the } \\
\text { belongings } \\
\text { and non-cases indicate } \\
\text { that belongings } \\
\text { be less well } \\
\text { sophisticated, } \\
\text { had more children and } \\
\text { skilled more } \\
\text { manifest (Husain et al., } \\
\text { 2000) }\end{array}$ \\
\hline Yes/NA & SWOT & $\begin{array}{l}\text { Searching } \\
\text { literature }\end{array}$ & $\begin{array}{l}\text { Not } \\
\text { available }\end{array}$ & $\begin{array}{l}\text { Planning } \\
\text { is very } \\
\text { poor, } \mathrm{HH} \\
\text { issues. }\end{array}$ & $\begin{array}{l}\text { Job } \\
\text { insecurity, } \\
\text { on } \\
\text { payment } \\
\text { of salaries }\end{array}$ & $\begin{array}{l}\text { For program } \\
\text { successfulness include } \\
\text { the political } \\
\text { elders, Mobilization } \\
\text { activities (Sharma et al., } \\
\text { 2013) }\end{array}$ \\
\hline $\begin{array}{l}\text { Yes/ } \\
\text { NA. }\end{array}$ & $\begin{array}{l}\text { Snow } \\
\text { ball } \\
\text { sampling }\end{array}$ & $\begin{array}{l}\text { Desk } \\
\text { review, } \\
\text { reports } \\
\text { documents } \\
\text { review }\end{array}$ & $\begin{array}{l}\text { Not } \\
\text { available }\end{array}$ & $\begin{array}{l}\text { Over } \\
\text { load and } \\
\text { no } \\
\text { supportiv } \\
\text { e } \\
\text { supervisi } \\
\text { on }\end{array}$ & $\begin{array}{l}\text { Not } \\
\text { available }\end{array}$ & $\begin{array}{l}\text { Community based } \\
\text { Strategies, respect and } \\
\text { acceptance from the } \\
\text { community (Jaskiewicz } \\
\text { \& Tulenko, 2012) }\end{array}$ \\
\hline $\begin{array}{l}\text { Yes/60 } \\
\text { FLWs. }\end{array}$ & $\begin{array}{l}\text { semi- } \\
\text { structure } \\
\mathrm{d} \\
\text { interview } \\
\mathrm{s}\end{array}$ & $\begin{array}{l}\text { semi- } \\
\text { structured } \\
\text { interviews, } \\
\text { UNICEF } \\
\text { report } \\
\text { (Closser, } \\
\text { 2011) }\end{array}$ & $\begin{array}{l}\text { All Pak } \\
\text { data }\end{array}$ & $\begin{array}{l}\text { Long } \\
\text { distance } \\
\text { but low } \\
\text { wages. }\end{array}$ & $\begin{array}{l}\text { L H W, } \\
\text { Risk Their } \\
\text { Lives; But } \\
\text { Do Not } \\
\text { obtain a } \\
\text { income. }\end{array}$ & $\begin{array}{l}\text { Building Stronger } \\
\text { partnership by means of } \\
\text { LHWs determination, } \\
\text { guide to factual Health } \\
\text { System intensification in } \\
\text { addition to } \\
\text { assist wipe out Polio } \\
\text { (Haines et al., 2007) }\end{array}$ \\
\hline
\end{tabular}

\section{DISCUSSION}

There are various kinds of stress that are especially to women who did jobs are disturbing an enormous segment of that population. The 2013 Stress \& Wellbeing survey, one out of four working women reported that they are feeling severe stress. It establishes men as well as women cover dissimilar reactions to stress, together physically and psychologically. More $\mathrm{HH}$ visits to given responsibilities, overload and extra work hours. Work and life balance management issue, putting extra hours during workwomen satisfaction level was also low and male field's exploitation that causes the stress. Psychological stress, particularly depression also its affect the work performance. World Health Organization (WHO) study suggest that stress level will become double after 5 years and it's a second leading reason in worldwide. LHV's face lot of issues during fields especially they cannot ride a motorcycle to access for flung areas. After review literature several aspects to be established in scheming and put into practice successful CHW scheme. The assessment keenly shows that (a) assortment of CHWs commencing the community they give out as well as (b) demographic- 
coverage along with the range of services accessible at the society level are fundamental within the intend of useful CHW scheme. It ought to be well-known that the minor the residents handling and cure the further included as well as demanding the examiner; obtainable by the FLW's. The degree to which extra factor ought to be in use into description is conditional on limited conditions, as well as economic plussocio-political factor. whereas the role of specific, gender, guidance, feedback, training, education along with monitoring system, and incentive with career projection, the financial resource foundations well as following promise will mainly determine the measure of attention these obtain in the mean and accomplishment of community health worker scheme (Haines et al., 2007).

\title{
Gap and Supportive Remarks
}

Most of the researchers not mention the G1,G2, G3 areas issue separately that is very important, LHV's are doing work but if one LHV,s purpose field activities she is pointed in G1 Area so this is soft area where as the other is pointed into G3 that is hard to reach and no facilities while salary is equal, so this gap that can be filled through equality biased, LHV,s purpose work into had to reach hard to reach pockets but cannot provide any security, LHV,s are doing work as a vaccinator into covered areas and uncovered areas that is not justifiable and as per government policy, During polio campaign LHV,s did work till late night that is not as per SOP's while government pay little , into village UC's. UC's are extra-large and LHV's are equally paid by the government that is not justifiable and it's against and question mark for all policy makers, its leading cause that in Pakistan we are unable to eradicated the polio, Communication staff is not doing work into maximum UC's government is very less interested to appoint the communication and mobilization staff into hard to reach pockets , HRP population on risk is not being properly vaccinated through vaccination, community elders are not being involved into $80 \%$ UC's for community health staff trust building. In rural areas $80 \%$ LHV's educated less than $8^{\text {th }}$ class other is F.A, FSC, B.A, BSC or master, those LHV's are less educated they do not have the capacity to understand the sop's and community session, interaction $40 \%$ areas are yet uncovering or not filled by the government due to dying cadre, LHV's are living into nearby cities for their children's better education that is against the policy, community cannot take advantage from the LHVs knowledge and experience. When LHV's move out of UC. Such things take lot of time and community face issue regards vaccination and health education. These are the main gaps and such causes lead towards stress. Lady health workers stress is an increasing dilemma particularly degree for field working women. The troubles due to maximum levels of stress; can be celebrated; actually, psychologically furthermore behaviorally. The most severe effects of stress narrate toward the work performance. It is suggested that government should take measures to improve lady health workers working conditions, increasing wages and decreasing workload by assisting them with modern technology.

\section{CONCLUSION}

After reading the maximum research papers it is concluded that there is lack of research on issues faced by forint line workers, Policy makers in addition to research organization are not taking actual information on the base of subjectivity that may be differ at al level. So the papers explained regard the managerial issues, low educated LHV's. Government new policies and less educated LHV's that facing issue regarding data sharing and field work. Work pattern changed for better planning and follow the equality on the base of distance, hard to reach pockets, fuel consumptions and motivation patterns. Behaviors change communication and resource allocation for awareness and community motivation especially into hard-to-reach areas. Social structure and LHV's movement especially during field, data collection, family support, office work and field work issue that face women's related to gender harassment, unequal wages and equal responsibility, equal wages and G3 areas work load, polio work from dawn to dusk and office explanations related to job performance, unequal distribution of resources and equal work performance expectation, over work load and human personal life especially family life, social disconnection and mental stress are directly linked with LHV's work performance its leading cause.

\author{
Abbreviation \\ Lady Health workers (LHWs) \\ Frontline workers (FLW's) \\ Union council (UC)
}


Household (HH)

Job descriptions (JDs)

Supplementary immunizations days (SID's)

Pregnant women's (PW)

Routine immunization (RI)

Heart rate variability (HRV)

Polio Eradication Initiative (PEI).

Community health worker (CHW)

World health organization (WHO)

Mother Neonatal Child Health (MNCH)

Primary health care (PHC)

Ladd health worker program (LHWP)

Interpersonal communication (IPC)

heart rate variability (HRV).

\section{REFERENCES}

Abdullah, R., Jahan, S., \& Saha, S. (2008). Occupational stress, social and family difficulties and job contentment of working women: Bangladesh perspective.

Anwar, T., \& Qureshi, S. K. (2002). Trends in absolute poverty in Pakistan: 1990-91 and 2001. The Pakistan Development Review, 859-878.

Arif, A., Naveed, S., \& Aslam, R. (2017). Factors causing stress among Pakistani working women. Pakistan Administrative Review, 1(3), 159-174.

Arif, B., \& Farooqi, Y. A. (2014). Impact of work life balance on job satisfaction and organizational commitment among university teachers: A case study of University of Gujrat, Pakistan. International Journal of Multidisciplinary Sciences and Engineering, 5(9), 24-29.

Bhuvaneshwari, M. (2013). A case study on psychological and physical stress undergone by married working women. IOSR Journal of Business and Management, 14(6), 38-44.

Tripathi, P., \& Bhattacharjee, S. (2012). A study on psychological stress of working women, International Journal of Multidisciplinary Research, 2(2), 434 - 445.

Chaudhry, A. (2019). Lady Health Workers in Pakistan: tracing personal and professional trajectories within a patriarchal context Queen Margaret University, Edinburgh].

Closser, S. (2011). Experiences and Motivations of Polio Eradication's Front-Line Workers in Pakistan.

Dodd, R., Palagyi, A., Jan, S., Abdel-All, M., Nambiar, D., Madhira, P., ... \& Peiris, D. (2019). Organisation of primary health care systems in low-and middle-income countries: review of evidence on what works and why in the Asia-Pacific region. BMJ global health, 4(Suppl 8), e001487.

Douthwaite, M., \& Ward, P. (2005). Increasing contraceptive use in rural Pakistan: an evaluation of the Lady Health Worker Programme. Health policy and planning, 20(2), 117-123.

Feltner, C., Peterson, K., Palmieri Weber, R., Cluff, L., Coker-Schwimmer, E., Viswanathan, M., \& Lohr, K. N. (2016). The effectiveness of Total worker health interventions: a systematic review for a National Institutes of Health pathways to prevention workshop. Annals of internal medicine, 165(4), 262-269.

Gyllensten, K., \& Palmer, S. (2005). The role of gender in workplace stress: A critical literature review. Health education journal, 64(3), 271-288.

Hafeez, A., Mohamud, B. K., Shiekh, M. R., Shah, S. A. I., \& Jooma, R. (2011). Lady health workers programme in Pakistan: challenges, achievements and the way forward. JPMA. The Journal of the Pakistan Medical Association, 61(3), 210.

Haines, A., Sanders, D., Lehmann, U., Rowe, A. K., Lawn, J. E., Jan, S., Walker, D. G., \& Bhutta, Z. J. T. 1. (2007). Achieving child survival goals: potential contribution of community health workers. 369(9579), 2121-2131.

Haq, Z., Iqbal, Z., \& Rahman, A. (2008). Job stress among community health workers: a multimethod study from Pakistan. International journal of mental health systems, 2(1), 1-6.

Husain, N., Creed, F., \& Tomenson, B. (2000). Depression and social stress in Pakistan. Psychological medicine, 30(2), 395-402. 
Jaskiewicz, W., \& Tulenko, K. (2012). Increasing community health worker productivity and effectiveness: a review of the influence of the work environment. Human resources for health, 10(1), 1-9.

Lehmann, U., \& Sanders, D. (2007). Community health workers: what do we know about them. The state of the evidence on programmes, activities, costs and impact on health outcomes of using community health workers. Geneva: World Health Organization, 1-42.

Lottrup, L., Grahn, P., Stigsdotter, U. K. J. L., \& Planning, U. (2013). Workplace greenery and perceived level of stress: Benefits of access to a green outdoor environment at the workplace. $110,5-11$.

Mumtaz, Z., Salway, S., Waseem, M., Umer, N. J. H. P., \& planning. (2003). Gender-based barriers to primary health care provision in Pakistan: the experience of female providers. 18(3), 261-269.

Murray, C. J., Lopez, A. D., \& Organization, W. H. (1996). The global burden of disease: a comprehensive assessment of mortality and disability from diseases, injuries, and risk factors in 1990 and projected to 2020: summary. World Health Organization.

Omer, K., Mhatre, S., Ansari, N., Laucirica, J., Andersson, N. J. P. e., \& counseling. (2008). Evidence-based training of frontline health workers for door-to-door health promotion: a pilot randomized controlled cluster trial with Lady Health Workers in Sindh Province, Pakistan. 72(2), 178-185.

Ronis, K., Nishtar, S. J. P., \& education. (2007). Community health promotion in Pakistan: a policy development perspective. 14(2), 98-99.

Sharma, R., Biedenharn, K. R., Fedor, J. M., \& Agarwal, A. (2013). Lifestyle factors and reproductive health: taking control of your fertility. Reproductive biology and endocrinology, 11(1), 1-15.

Swathi, V., Reddy, M. S. J. I. J. o. C. E., \& Management. (2016). Stress among working women: A literature review. 19(4).

Thayer, J. F., Åhs, F., Fredrikson, M., Sollers III, J. J., \& Wager, T. D. (2012). A meta-analysis of heart rate variability and neuroimaging studies: implications for heart rate variability as a marker of stress and health. Neuroscience \& Biobehavioral Reviews, 36(2), 747-756.

Zaidi, S., Kazi, A. M., Riaz, A., Ali, A., Najmi, R., Jabeen, R., ... \& Sayani, S. (2020). Operability, usefulness, and task-technology fit of an mHealth app for delivering primary health care services by community health Workers in Underserved Areas of Pakistan and Afghanistan: qualitative study. Journal of Medical Internet Research, 22(9), e18414.

Zarra-Nezhad, M., Moazami-Goodarzi, A., \& Hasannejad, L. (2010). Occupational stress and family difficulties of working women. 